\title{
Es ist so weit!
}

Die neue Homepage der ÖGIM ist online gegangen.

Sie hat nicht einfach nur ein moderneres und dadurch ansprechenderes Layout als die alte Homepage, sondern entspricht auch in ihrer Funktionalität den Anforderungen der heutigen Zeit. Aktuelle und wichtige Informationen sowie den Zugang zum Passwort geschützten Mitgliederbereich finden Sie in übersichtlicher Anordnung auf der Startseite, die weiteren Inhalte sind leicht abrufbar und gut strukturiert dargeboten. Einen wesentlichen Platz in Layout und Inhalt nehmen die Additivfächer ein. Die ständig wechselnden Bilddarstellungen auf der Startseite symbolisieren die Vielfalt der Inne- ren Medizin, während in den Seiten, die den Additivfächer gewidmeten sind, diese ihr eigenständiges Profil darstellen.

Ich hoffe, dass sich die neue Homepage der ÖGIM für ihre Mitglieder und für Internisten insgesamt $\mathrm{zu}$ einer anregenden und häufig besuchte Website entwickeln wird!

Ihr

Univ.-Prof. Dr. Herbert Watzke ÖGIM-Präsident

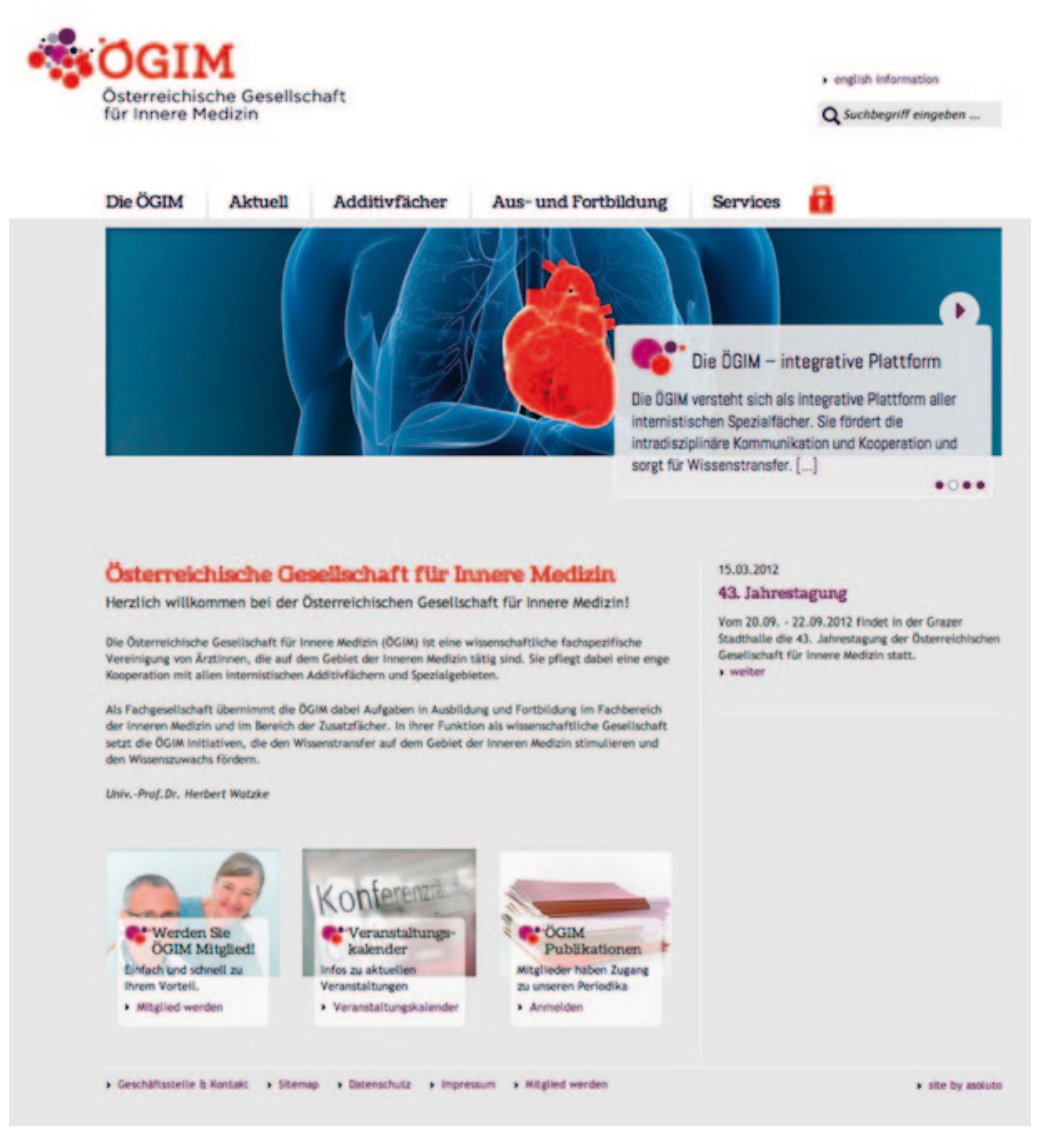

